\author{
Rémy Rousseau The rise of the "artist" in Burkina Faso \\ Rémy Rousseau is a Ph.D. candidate \\ in Art History at Université \\ Panthéon-Sorbonne, Paris. \\ E-mail: remy.rousseau1@libertysurf.fr
}

\title{
The rise of the "artist" in Burkina Faso
}

It is only during the last twenty years that contemporary art has found actors in Burkina Faso. Thomas Sankara's revolutionary regime was the first to offer artists a frame to promote and perfect their technique. During the 1980s, the Semaine National de la Culture (National Week of Culture), the Pan-African Film Festival of Ouagadougou (Fespaco), and the Salon International de I'Artisanat de Ouagadougou (Ouagadougou International Handicraft Show) were the only major projects that allowed artists to learn new techniques and to be known. However, because Thomas Sankara's government expected the creators to participate in the revolutionary project, this left them little space for innovation and the expression of their artistic freedom. The early 1990s saw the rise of new events, which at last offered artists a space to practice their art, based on personal inspiration and competence in artistic technique. The Laongo symposium of granite sculpture, PIAMET (an event started by two well-known Burkinabè artists), and Ouaga'Art (organised by the French Cultural Centre of Ouagadougou) thus offered young artists the possibility of discovering the techniques of their colleagues from Africa and elsewhere in the world. However, except the Olorun Foundation, there is no permanent space dedicated to training and artistic exhibition. This lack is a source of obvious problems for the creator who, as a result, may find himself entrenched in a circuit where commercialism seems to dominate artistic research. Key words: contemporary artist, plastic artist, artistic teaching.

During the second half of the $20^{\text {th }}$ century, some African countries experienced a birth of artistic schools and movements contemporaneous with the 1960s "wave of independence." The budding urban centres then began to express new visual codes and introduced artistic practices previously unheard of in numerous African countries. The schools of Poto-Poto in Congo, Oshogbo and Zaria in Nigeria or the NegroCaribbean school of Côte d'Ivoire, to name but a few of these, had already been training renowned and aspiring artists. Contemporary art in Burkina Faso on the other hand is quite recent. It has emerged only over the past fifteen years, and its major contributors are just starting, since the beginning of this millennium, to show up at international meetings on contemporary art. What are the origins and developmental stages of the artist in Burkina Faso? This is the question I am considering in this study. For the sake of clarity, some definitions are necessary. The "artist" here is the one who, while assimilating the concept of "art for art's sake" imported by colonization, is 
required to involve himself in the act of creation and transpose the emotion or interest of artistic practice, no longer in conveying a (religious, symbolic, social) message or its representation, but in the creative act. The purpose of the artist lies therefore in involving his person or personality in the very moment of making the image. The emotion contained in the representation no longer derives from its appearance, but from what is left of the creator's experience at the time of the composition.

\section{The late emergence of contemporary art in Burkina Faso}

I shall examine here how the colonial, pre-revolutionary, and revolutionary times have led the entire Burkinabè people to become aware of their own responsibilities to forge their personal identity. These being essential phenomena for the emergence of the artist as defined above.

As it were, before the 1983 Revolution (the advent of Thomas Sankara's regime), suffering the consequences of colonialism, the Burkinabè people had learned how to take care of their country's cultural and political life, without any political or centralized media. It is impossible to consider here all the phenomena induced by French colonization and their effects on the mentalities of the people of Upper Volta (former name of Burkina Faso). Those mentalities being, I believe, the foundation for the formation of a Voltaïc identity. However, such factors as the country's geographical position, the fragility of the borders of Upper Volta, ${ }^{1}$ and the political regime that the colonial administration intended to impose on the Voltaïc people, had at least the merit of strengthening the capacity of resistance and solidarity both among the Burkinabè elite and the larger population. Indeed, when the situation demanded it, the Burkinabè people were able to make the authorities hear them. They even succeeded in playing a considerable role in the access to power or dismissal of various regimes that ruled the country. In 1966, they toppled President Maurice Yameogo. At the end of 1975, following the advice of his peers Eyadema of Togo and Mobutu of Zaire, the next president, Lamizana Sangoulé, decided to create a single party, the Mouvement du Renouveau National (National Revival Movement). This resulted in a general strike on 17 and 18 December 1975, which paralyzed the economic and social activity in the whole country and foiled the project. I mention these episodes before touching on the field of arts and culture per se, because I want to account for the involvement and responsibility of each Burkinabè or ex-Voltaïc person in the country's political life. This is an attitude of collective awareness raising which has also imprinted the cultural life.

During the 1960-1970 decade, the public authorities were practically absent from the cultural sphere. The institutions active on this terrain were the different private schools, the university, and ethnic associations, including intellectual associations like the Association Voltaïque pour la Culture Africaine (ACVA, Voltaïc Association for 
African Culture). The ACVA, created in 1963, organized public conferences, started a journal, Voies d'Afrique ("Ways of Africa") in 1965, and supported theatre companies. Another such association was the Cercle d'Activités Littéraires et Artistiques de HauteVolta (CALAHV, Club of Literary and Artistic Activities in Upper Volta) created in 1966, and which, considering its various activities, may be regarded as a surrogate of the Ministry of Culture. The latter association played a considerable role in the promotion of art and research in Upper Volta by organizing radio cultural programmes, public conferences, and cultural events with tours abroad, as well as major literary and artistic competitions. It must be noted that these associations had a nationalist and pan-African character, which showed in their activities. Indeed all of them claimed to bring Africans together around a rehabilitated and specific culture proper to the Black continent; and they were strongly encouraged by the consecutive independence period notions of Pan-Africanism and negritude propounded by Leopold Sédar Senghor in Senegal or by Kwame Nkrumah in Ghana.

Initiated by these first African presidents, these processes of mind change (Africans becoming proud of being Africans; Africans taking responsibility for their culture) reflected in a series of events that occurred during the decades of the 1960s and 1970s. These events compelled the Voltaï government to react against its absence from the field of culture: the creation of the Organization of African Unity in 1963, the Festival of Negro Arts in Dakar in 1966, the Pan African Festival of Algiers in 1969, and the creation of the African Cultural Institute in 1971.

It is in this context that the Voltaïc authorities decided to create a department of Culture, initially under the Ministry of National Education. This new state-related structure was supposed to manage all cultural events, including those initiated by civil society. However, the latter was not happy to see the new structure divesting it of certain functions in the area of culture.

\section{Between encouragement and censorship: the Sankarist Revolution (1983-1987)}

Under the Revolution, the main concern of the leaders was to specify the role and place of culture in the revolutionary process. To this end, Thomas Sankara took advantage of the 2 October 1983 Discours d'Orientation Politique (DOP, Political keynote speech) to define the triple character of the Popular Democratic Revolution: national, revolutionary and popular. The DOP was part of a societal programme designed by the new soldiers in power, and it gave the citizens a role to play in this new society. If the speech remained evasive on the conditions necessary to encourage artists, for instance by projecting to put in place "enabling conditions for the blossoming of a new culture," it was very precise on the method. It called on writers "to put their pens at the service of the Revolution" and on musicians "to sing the glorious past of [the] People," including "their radiant and promising future." In a general way, it expected 
all artists to "know how to describe reality" (Thomas Sankara quoted in Otayek 1996: 82-83). ${ }^{2}$ Thus, artists were placed at the forefront of the struggle of the Burkinabè people do build the new society as imagined by the Revolutionary Regime. They were encouraged to draw inspiration from the national heritage in order to raise the awareness of the people and educate them. A similar task was also assigned to the artists at the Séminaire National sur la Culture (National Seminar on Culture) held on 22-28 April 1984 at Matourkou on the theme Voies et moyens pour la promotion d'une culture nationale ("Ways and means to promote a national culture").

Burkinabè culture and arts suddenly held a crucial place in the Conseil National de la Révolution's (CNR, National Revolutionary Council) policy. These were considered as tools for changing mentalities through revalorizing cultural inheritance and promoting the arts, and as tools for popular mobilization. The goals of this policy were first to strengthen the national identity of the Burkinabè community and to enable it to affirm its identity by rejecting the cultural and mental alienation generated by colonization. The Semaine Nationale de la Culture (SNC, National Week of Culture) that the CNR organized from the inception of its power therefore offered the artists an opportunity to discover the various traditional artistic practices in Burkina Faso and to enrich themselves through contact with them. If the proclaimed objective was to preserve traditions and encourage their modern expressions, while improving the quality of performances and productions, the fundamental concern clearly remained the search for tools likely to serve the causes and objectives of the Revolution, fairly and with dignity. The themes of the competitions organized as part of this festival naturally drew much from the great calls of the Revolution. Commenting on those themes, one unknown journalist observed that they evidenced "patriotism through calling for national unity and the building of the nation" and that "the artist became the propagandist of the CNR's slogans." ${ }^{3}$ However, by operating on a rotation system, the convention of the SNC equipped many provinces with cultural infrastructure.

Despite all, the Revolution clearly exposed artists to modern techniques and new modes of expression. A number of artists, indeed, were sent to Europe at that time to learn new techniques. The CNR officially ordered monument sculptures to assert and mark the important achievements of the Revolution. This initiative allowed such artists as Ali Nikiéma, Siriki Ky, Guy Compaoré, and Tassiré Guiré to benefit from training in monument casting technique in Italy in the middle of the 1980s. These artists are still today references as regards Burkinabè sculpture. Meetings were organized between the two bronze smith centres of Ouagadougou and Bobo Dioulasso to help them discover the specific styles and techniques of the two "schools". The Revolution also conducted large public awareness campaigns with wide boards placed at the most important crossroads of Ouagadougou. Artist Kou Lougué took the greatest advantage of this initiative. Working generally on $2 \times 5$ metre surfaces, he dealt 
with various topics he deemed could encourage Burkinabè people to adapt, for their own good, to the novelties that the Revolution was providing them: air transport, public transport, new housing styles, etc. Concerning education, the revolutionary regime restarted what we may call "entertainment activities" in schools (offering students the possibility to practice various artistic disciplines). In September 1985, with the assistance of the Cuban Co-operation, it opened the Académie Populaire des Arts (Popular Academy of Arts). This Academy offered courses in fine art, music, dance, and theatre, but it seems that the focus was more on academic drawing, which preached objective realism dear to any revolutionary period. The point was not to cover all the techniques available in Africa and to make the would-be artists conscious of the expressive potential of artistic creation, but, once again, to create artists likely to serve the regime. The CNR also undertook another commendable initiative: the Salon International de Ouagadougou (SIAO, International Craft Show of Ouagadougou). Since this festival only dealt with craft or utility works, it should not detain us further. Suffice it to note that, as an international trade show, it has had the merit of introducing Burkinabè people to international craft creations. As for the administrative level, the following key events may be noted: the Department of Culture continued to be nomadic, the Burkinabè Copyright Bureau was set up in 1985, and the creation of L'Institut des Peuples Noirs (the Institute of Black People) in 1986 expanded the quest of identity to include the Diaspora.

If the Revolution gave the artists institutional support, which increased artistic production in Burkina Faso, it does not seem to have favoured free creation. Exploited ideologically and used as a tool for the promotion of a political programme, the artist has not been encouraged to be free. Though the pen was not exactly in the service of the sword, the hand no longer was the tool of a community of beliefs and practices, but of a societal programme imposed on the artists which they were expected to promote to the detriment of their personal aspirations.

\section{The beginning of an expression framework in Burkina Faso}

Taking over the management of the Centre Culturel Français (CCF, French Cultural Centre) in Ouagadougou in September 1991, Guy Maurette made his objectives clear in his programme report: to make CCF a place of discovery of languages and aesthetics, and assist the emergence of Burkinabè talents. As early as 1992, he started all kinds of musical, handicraft, and artistic events, including Ouag'Art, through which he aimed to make up for what he perceived as a dearth of creators and fine artists in Burkina Faso. I choose to discuss Ouag'Art in this paper for multiple reasons. On the one hand, the majority of the fine artists now evolving in Burkina Faso originated from it; on the other hand, Ouag'Art was then the only training venue exclusively targeting contemporary or personal artistic creation. I find that the organizers of 
Ouag'Art have been insightful in terms of coping with the specific needs of artists, especially African artists, and in the way they responded to these, point by point, throughout the five editions, from 1993 to 1998.

From a technical point of view, the sculpture training courses (organized many times by Henri-George Vidal, a French sculptor) enabled the learners to discover lifelike modelling as well as numerous materials accessible on the spot, like paper, paperboard, plaster, fabrics, wrought and forged iron. A large part of the training courses was also devoted to the live model drawing approach, which constrained the trainees to face the difficulty of observing the rules of proportions and representation of the human anatomy. In painting, As M'Bengue (a Senegalese painter) concentrated with his interns on perspective and still-life drawing, including frame building, preparation of canvas and colours according to the choice of pigments. Teaching the future designers François Kiéné endeavoured to take them through all the stages of the process of realizing pieces of furniture or objects. His courses entailed a study of the concepts of ergonomics, sketches, drawings, models and design.

Thus, whatever the discipline concerned, the training informed the trainees on the various phases of artistic creation, from the choice of pigments to the maintenance of the material, as well as the basic rules on perspective, the representation of volumes or of human anatomy. In addition, they received a number of different materials to enable them to operate choices within their acquired reference frame. The stress in these workshops was laid resolutely on the artist's freedom and on the importance of acquiring the most adapted tools (discipline, material, technique) for his "creative flame" and expressive needs through this artistic practice. I now get to the second character of the artist developed through Ouag'Art, that is to say, the artist's own personality, his culture and the importance for him to tap into the reasons for his creative act, what Vidal (1993: 3) called in his training courses the encounter of l'humain et l'artiste ("the human and the artist").

Indeed, Vidal focused the first sculpture-training course on the theme of "the human and the artist." According to him, he chose this theme because of "the importance of human representation in the statuary in general, and especially in the African one." After visiting some workshops where he met Burkinabè artists, he further felt that "the main deficiencies in the training offered to young people have to do with lack of rooting in their culture and their ignorance of their artistic heritage." Since the stated goal was to sensitize the young Burkinabè artists about the richness of their culture, they spent the bulk of their days in the library of CCF to do research on their own culture and the African statuary. During these training sessions, Vidal taught them the representations and interpretations of the body in different civilizations and at various times in history, the deformations of the anatomy, the symbolization of certain parts of the body, including the different ways of stressing or overshadowing these and of course their significance. In the same way, François Kiéné too had 
invited his first students to study their own culture, history, traditions, each according to his ethnic origin. Aiming "to make these artists absorb the new demands of contemporary painting, and cultivate their individual personalities." ${ }^{5} \mathrm{M}^{\prime}$ Bengue (1994: 18) worked with them on the symbolism of colours, their significance and evocative potential, and insisted on the traditional symbolic system.

Lastly, another positive aspect that must be noted is that, from the first edition, the organizers chose to direct this event at the local craft artists eager to rise beyond the handicraft market in order to ensure a demand and a market for the artists at the end of their training." Random exhibitions" and sales were organized at CCF. Some organizers of Ouag'Art also contacted limestone-mining companies in the area of Bobo-Dioulasso and geologists to make materials available to the learners. The objective was also to open partnership outlets with industrialists, who were interested in the artists' new forms. Integrating artistic practice into an existing commercial network was a way of facilitating its expansion.

As it were, Ouag'Art has contributed to certain autonomy for Burkinabè artists. Through the technical, conceptual and economic responses described above, it has met their specific needs as African students: the deficiencies that had struck the organisers and led them to create Ouaga'Art. ${ }^{6}$ The aim of these professional organizers was to provide the creators with much artistic practice. The artists became aware of the potential and solutions of plastic art and techniques proper to each form. Consequently, they could decide, through choice and not through dislike or inexperience on the technique that best served their expressive needs. The artists' study of their cultures and their traditional modes of expression gradually led them to consider the relations between the "individual artist" and his culture, his own sensitivities, the world around him. The aim and outcome of this empowerment process were to justify the young creators' artistic practice, no longer in response to any ideological or pecuniary request, but only with respect to the specificities and techniques of art and the artist's personality. This method gives the artists certain autonomy, to recognize plastic art creation by what distinguishes it from other (traditional, artisan, commercial) practices, and by what characterizes it as an expression originating in a heritage that is not just cultural, but also "intimate, personal".

\section{Restricted and oriented frames of expression}

Ouag'Art introduced the artists of Burkina Faso for the first time to a "free" form of plastic art creation. However, the Burkinabè governmental administration did not have anything to offer the artists, anything that could help them pursue the process launched by CCF. Hereunder are some institutions or workshops, which retrieved these creators or remained available to them. I will identify their advantages and disadvantages arising from the artists' work or "outcomes." 


\section{Le Centre National d'Artisanat d'Art}

Originally, Le Centre National d'Artisanat d'Art (CNAA, the National Handicraft Art Centre) was the initiative of a group of young bronze smiths then located on the edge of the Ouagadougou Dam in Niongsin, a neighbourhood dating back to the arrival of bronze smiths in Burkina Faso at the end of the $19^{\text {th }}$ century. The French Co-operation created the centre in 1967 to promote and foster artists and handicraft workers. 60 worked at CNAA at the beginning of 1990s and 113 in 2000. However, it seems very difficult to give a definite figure since no contract binds CNAA to the artists who work there. Most of the artists indeed seem to have come to CNAA by cooptation.

The main objective of CNAA was to train fine artists who, after completing their training, left the Centre to start their own businesses. Nevertheless, most of the artists remained at CNAA: some have been there since its inception; others for eight, ten, even fifteen years. Moreover, the training being purely practical, non-formal, the trainees only learn on the job, through their more learned comrades. The workshop officers and the management have not developed any clear curricula or pedagogical methodology. A "traditional" type of learning has therefore been perpetuating over more than thirty years, one in which the relationship between artists is more a master and apprentice-type than a real exchange between professors and students. This attitude reflects an uncertain policy, which deprives the Handicraft Art Centre of the autonomy necessary to develop theoretical and technical courses, that is to say, professional ones. With this, the Centre could have avoided being treated as amateurish and "ethnically" based. Indeed, my study goes back to 2003 and according to the management reports of the Ministry of Arts and Culture (2000, 2001), it seems that CNAA received no investment for at least three years. In other words, this means that the Centre had no chance of starting anything in terms of artistic training or exchanges, which could offer its artists the opening and challenges essential for artistic innovation and creation. The bulk of the fine artists now operating in Burkina Faso received their training at CNAA. Unfortunately, the Centre has only been a craft production venue for them. It has not been able to award them diplomas recognized by the State which would have allowed them to practice their profession as artists, as well as ensured their status as independent artists.

\section{Olorun Foundation}

The Olorun Foundation, esablished in 1993 under a 1901 statute governing associations, was chaired by Christophe de Contenson, who two years previously managed the Maquis Le 56, a bar-cum-restaurant common in Burkina Faso and Côte d'Ivoire, in the neighbourhood of Dapoya. When Olorun opened, the employees of the maquis converted into creators and produced the first works for the initial exhibitions of the Foundation. 
However, it was the first edition of Ouag'Art that really helped the Foundation to take off, when the trainees recognized Olorun as the only permanent structure dedicated to the arts. It provided them with the material they needed and a marketing place, because it regularly organized exhibition trade shows. Being the only available creative space between Ouag'Art editions, Olorun Foundation indeed contributed to greater visibility for Burkinabè artists who emerged at the beginning of the 1990s. It organized various national and international cultural and social programmes, which enabled its artists to meet other creators within the Foundation in Burkina Faso and abroad. In spite of these positive aspects, it seems however that the artists of Olorun never received any formal and specific training, except those offered by Blaise Patrix as part of the 1995 edition of Ouag'Art. Mostly, the younger artists learn from the more experienced ones. Often, they are given opportunities to rub shoulders with visiting professional artists and to learn where to locate the "true market" from the knowledgeable ones.

Marie-Pierre de Contenson, a sister of the Foundation's manager, said: “Though their customers, initially exclusively made up of expatriates and tourists, tend to diversify, the creators of Olorun principally work for the Western World, where [...] "the true market" is located. "At the beginning, I used to explain to them the concepts of objects likely to please Westerners, and from there they explored what they could make with the local techniques and materials. Since, they have made their way, they take account of the potential market trends, but they translate these into their own way, and therein lies their true creativity" (quoted in Andriamirado 2001: 28). ${ }^{7}$ Some of the artists came from a craft production system characterized by a crushing hierarchy. Some others were trained at Ouag'Art to approach art from a personal perspective. In either case, a process was imposed on the artists to the detriment of their personal needs of self-expression, a creation process targeting a hypothetical demand with codes and rules to be observed. This practice clearly thwarted the kind of association that Olorun offered them. As it were, this association, which preferred the cabinet style concept to that of artistic hearth or workshop, did not completely succeed in substituting for Ouag'Art. This was due to the functioning of the Foundation. The Foundation compels the managers, acting as both hosts and agents for the artists, to direct the production of the artists who are sanctioned systematically and regularly during the exhibition trade shows. This operation does not aim to free the artists; instead, it further binds them to the Foundation and to the kind of creation that it alone identifies as "profitable" and thus worth "reproducing". I do not mean to refute the economic imperative, which primarily governs artistic creation in the contemporary meaning of the term. This is a pressing dimension in one of the poorest countries of the world. However, it is risky to consider their dissemination before providing the artists with the best means of expression, before working with them to make their creation serve best the African artist, and the Burkinabè artist in particular. Introduc- 
ing craft artists to artistic practice in terms of personal expression must encourage them to acquire and develop as many technical processes as possible. Indeed, these can lead them closer to an inner sense of creation, as they research and work. In terms of approach and evolution, development and progression, or else the satisfaction procured by the practice of art, I believe that this awareness of the potential of art and thus of the artists themselves is of paramount importance and even comes before anything else. Failing that, the Burkinabè artists will remain destitute, such as I have often seen them, exposed to the anxiety and uncertainty of simply being copied, as well as dishonest to their peers, their customers and themselves.

Christophe de Contenson in an interview in 1990 indicated the devastating impact quick success had on the artists trained at Olorun, or rather, on their works. These artists "dried up" and revealed their vision of their art as a means rather than an end: "for many a simple social recognition". This attitude resulted in a reductive and hardly evolutionary vision of creation. De Contenson's analysis on the competition and absence of dialogue and circulation within the artistic community is compelling. I believe that this situation has to do with the organization of Olorun and the way it introduced artistic practice. What this manager is depicting is a creation particularly directed towards the customer's expectations, satisfying the demands of Westerners, and thereby placing the artist in a situation of permanent lie masked by a veil woven for foreign consumers. But reconciling Olorun's diverging objectives with the training courses of Ouag'Art may reveal the origin of the positioning of the artist trained in the private foundation, and which De Contenson himself seems to condemn.

\section{Initiatives of artists}

After presenting the events and structures bearing on fine artists, their training or promotion, I now want to celebrate their own initiatives, which have helped to bring them together, it seems, around a common artistic practice. An exhaustive list of these projects would be tiresome and not very necessary: I have selected three of them, those that appear to me as more representative and significant.

The Laongo symposium of sculpture on granite has been an important artistic event in Burkina Faso since 1989, thanks to the efforts of a reputed sculptor, Siriki Ky. Located 35km north-east of Ouagadougou in the province of Oubritenga, the symposium takes place at the same time as the Fespaco, the Burkinabè Film Festival. Every two years, it gathers numerous people from abroad, and perfectly meets the requirements of the développement du tourisme culturel ("development of cultural tourism") to which it is supposed to contribute (Kiethga 1989: 37). Initially, the idea was to bring together artists from all the continents so that they could compare their artistic techniques and approaches of sculpture on granite, with the ultimate objective of establishing an artistic residence system for the benefit of the participants. The success of 
this initiative was such that as of the second edition, it became necessary to build an artistic village. Called Yambfaa, the village was to provide accommodation for the artists near the outcrop offered by the site. Its construction also translates the will of the authorities to keep the site permanently lively during the symposium and thus make it a true tourist attraction likely to accommodate foreigners throughout the festival. In 2003 when I visited the symposium, it was holding its sixth edition and boasted more than one hundred sculptures.

The artist Bomavé Konaté won several awards at SNC between 1984 and 1988. A descendant of a family of traditional blacksmiths, he created the Sini-Landa association, which in his native language Jula means "for the future". In an interview, he contends that his aim is to "reconstitute Africa" (Konate 1990). Sensitive to the disappearance of traditional ways of life, the looting of ethnological, cultural and artistic riches, as well as the disintegration of communities resulting from the new way of life copied on the Western mirage, Konaté acts as a custodian of African culture and its conservation on the black continent. In 1995 he created the first meeting of the Parc International des Arts Modernes et Traditionnels (PIAMET, International Park of Modern and Traditional Arts), with a view to rebuilding the African heritage through establishing an agency of intercultural exchanges. PIAMET offers residence to participants from different origins. The first edition in October 1995 brought together 58 artists from Austria, Chile, France, Germany, and Burkina Faso. The artists contribute, through their productions to the construction of an open-air museum of traditional and contemporary art works. The idea was also to allow Burkinabè and European artists to exchange and compare their practices, as these present different meanings and perceptions of creation. Indeed, it seems that the artists and the visitors as well as the locals perceived creation as an integral part of life. Therefore, the artistic creations did not remain bunged up within the museum; some were presented outside at real artistic performances directly for the local people. In the same spirit of liberating and democratizing art, in 1998, Bomavé Konaté carved on the market place a tree trunk in the shape of a person holding a camera whose lenses were replaced with a mirror reflecting for the merchants and customers the market scenes that they were acting out. By setting their creations within the rural and social fabric these initiatives testify to the desire of the artists to communicate to the Burkinabè a new vision of art, such as that practiced at the PIAMET in Boromo.

The Association Nationale des Professionnels des Arts Plastiques (ANAPAP, National Association of the Professionals of Fine Arts) created in October 2000 in Ouagadougou, is managed by an executive committee re-elected every three years. It was initially funded as part of the Programmes de Soutien aux Initiatives Culturelles (PSIC, Cultural Initiative Support Programme), a programme launched in 2000 by the European Union to support cultural projects in West Africa. According to its constitution, the specific objectives of the association are to ensure an adequate artistic training for its mem- 
bers, to improve and protect the artists' economic status through a hire purchase system for their artistic productions, to contribute to sensitize and educate the people on art, and to stimulate exchanges between national and international artists. The association has also opened a bank of art works, computerized data on artists, specialized works and periodicals (sold or rent), the Artothèque, to provide fine art-related information to the public as well as to students. The hire purchase system aims at encouraging households, banks, embassies, hotels, agencies and NGOs to acquire art works at a lower cost. With this policy, the association hopes to bridge the business world and that of fine arts in order to ensure a livelihood for its members.

This quick overview of the stages, from the traditional artist through the artisan to the contemporary Burkinabè artist, cannot obviously capture all the events that have contributed to the blossoming of the young talents that have emerged in this country. Unfortunately, many of these events were geared towards trade rather than serving the Burkinabè artistic community. Yet, it is in the interest of fine artists to train and enrich themselves through contact with both their Burkinabè and foreign colleagues. Without this framework addressing the technical and conceptual requirements exclusively, which determine the artist's creative course, the Burkinabè artist, and more generally the African artist, runs the risk of finding no place, either in his own society or in the history of African art, but only in a market catering for foreign and Western tastes.

Translated by Roger Issa Coulibaly and Amadou Bissiri

\section{Notes}

1. Upper Volta was dismantled between 1932 and 1947, to facilitate the movement of workers between the French colonies.

2. "des conditions propices à l'éclosion d'une culture nouvelle", "mettre leur plume au service de la Révolution", "à chanter le passé glorieux [du] Peuple", "son avenir radieux et prometteur", "savoir décrire la réalité" (Thomas Sankara quoted in Otayek 1996: 82-83).

3. My thanks to Bakary Koumon, an officer of SNC's Permanent Secretariat in Bobo Dioulasso, for this anonymous paper, "Fine Art Exhibition".

4. "de l'importance de la représentation de l'humain dans la statuaire en général et africaine en particulier"; "apparaît que les principales carences dans la formation des jeunes est le manque d'enracinement dans leur culture et la méconnaissance des oeuvres du patrimoine" (Vidal 1993: 3).

5. "d'amener ces artistes à s'imprégner des nouvelles exigences de la peinture contemporaine, de cultiver la personnalité de chacun" (M’Bengue 1994: 18).

6. I try to explore these responses, but up to the present, no appropriate one has yet been found as to what exactly to inculcate in African creators caught been tradition, openness to international art history and economic imperatives.

7. “Même si la clientèle, d'abord exclusivement composée d'expatriés et de touristes, tend à se diversifier, les créateurs d'Olorun travaillent en direction de l'Occident, là où [...] se trouve "le vrai marché" [...] Au début, je leur expliquais les concepts des objets qui pouvaient plaire aux Occidentaux et à partir de là, ils réfléchissaient à ce qu'ils pouvaient faire avec les techniques et les matériaux locaux. Depuis, ils ont fait leur chemin, ils tiennent compte des tendances des marchés potentiels, mais ils les traduisent à leur façon et là se situe leur véritable créativité " (Marie-Pierre de Contenson quoted in Andriamirado 2001: 28). 


\section{Works cited}

Andriamirado, Virginie. 2001. Fondation Olorun: quand création rime avec marketing. Africultures N'38: 102-103.

Anonymous. N. d. Fine Art Exhibition. N. p.: n. p.

Centre Culturel Français Georges Méliès. 1999. Rapports d'activité du Centre Culturel Français Georges Méliès de Ouagadougou de 1987 à 1999. Ouagadougou.

Fall, N'goné \& Pivin, Jean-Loup. 2001. Anthologie de l'art africain du XXème siècle. Paris: Editions Revue Noire.

Gaudibert, Pierre. 1994. Art africain contemporain. Paris: Cercle d'Art, collection "Diagonales".

Guissou, Basile. 1995. Burkina Faso, un espoir en Afrique. Paris: L’Harmattan.

Kamba, Rasmané. 1994. Présentation générale du Centre Nationale d'Artisanat d'Art. Adressé au Ministère de la Culture, Secrétariat général courant.

Kiethga, Jean-Baptiste \& Kiendrebeogo Samuel. 1989. Sympo Granit 89. Ouagadougou: Imprimerie Nouvelle du Centre.

Konaté, Bomavé. 1990. Unpublished personal interview. Ouagadougou (13 0ctober).

McEvilley, Thomas. 1999. L'identité culturelle en crise, Art et différences à l'époque postmoderne et postcoloniale. Nîmes: Jacqueline Chambon.

Ministère des Arts et de la Culture. 2000. Rapports d'activités du Ministère des Arts et de la Culture. Ouagadougou

. 2001. Rapports d'activités du Ministère des Arts et de la Culture. Ouagadougou.

Otayek, René, Sawadogo, Filiga Michel, Guingane, Jean-Pierre (eds.). 1996. Le Burkina entre révolution et démocratie (1983-1993). Paris: Karthala.

Ouedraogo, Mahamoudou. 2001. Livre Blanc sur la Culture. Ministère des Arts et de la Culture, Découvertes du Burkina, Ouagadougou.

Sankara, Thomas. 1996. Discours d'Orientation Politique. In René Otayek, Sawadogo, Filiga Michel \& Guingané, Jean-Pierre (eds.). Le Burkina entre révolution et démocratie (1983-1993). Paris: Editions Karthala, 82-83.

Ströder-Bender, Jutta. 1995. L'Art Contemporain dans les Pays du "Tiers-Monde". Paris: L'Harmattan.

Tiendrebeogo, Prosper. 2000. Dynamisation du CNAA - Bilan des activités et perspectives, Ouagadougou, décembre.

Yeye, Zakaria. 1993. Ouag'Art 93, le rendez vous des artistes plasticiens. Sidwaya n²249: 23-27.

Vidal, Henri-Georges. Report on Ouag'Art 93 Sculpture Workshop. Ouagadougou.

Vidal, Henri-Georges, Kiene, François, Patrix, Blaise, M’Bengue, As. 1994. Rapports des stages Ouag'Art. Ouagadougou.

1995. Rapports des stages Ouag'Art. Ouagadougou.

1996. Rapports des stages Ouag'Art. Ouagadougou. 